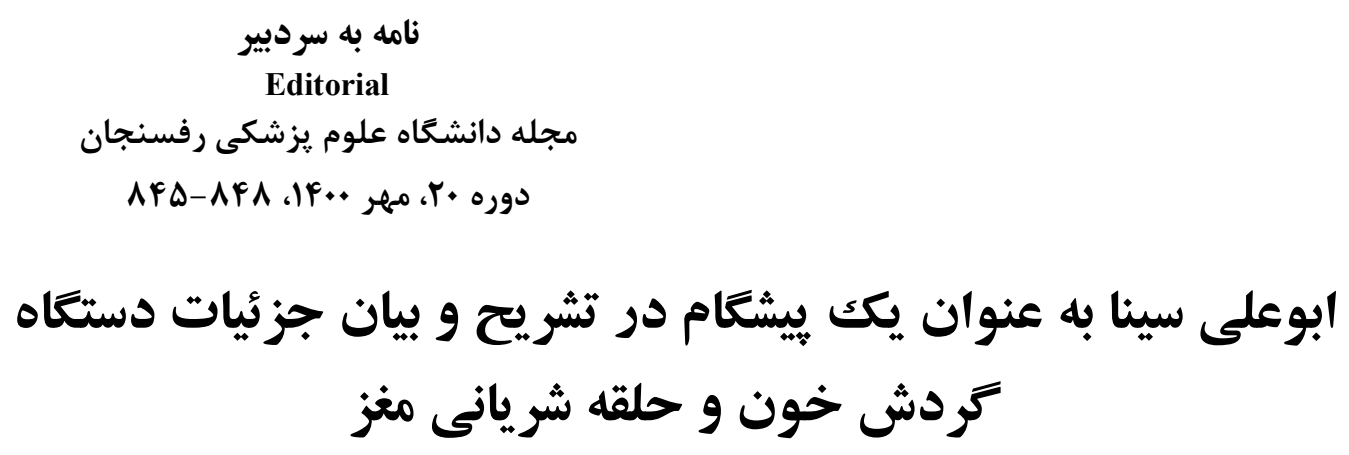

\title{
Ibn Sina as a Pioneer in Dissection and Description of the Circulatory System Details and Arterial Circle of the Brain
}

عبدالرضا بابائى '، سامره دهقانى سلطانى '، زهر ا تقىيور شول '، احمد شبانى زادهء؛ محمد محسن

ينشك (به زبان آلمانى Der Medicus، به زبان انغليسى (The Physician محصول (سال rا • r) كشور آلمان است. حوادث اين فيلم مربوط به قرون وسطى و زوال علوم تجربى، به ويزه علم يزشكى در ارويا و توجه مردم به خرافههاى مطرح شده توسط سودجويان و با نام كليسا مىباشد. در همان زمان در سرزمينهاى اسلامى به ويزه ايران دوران طلايى شكوفايى علم بود. در اين فيلم فردى به نام راب كول كه اهل انغلستان است در شهر خود بادورهردى آشنا مىشود كه برخى فنون يزشكى و از جمله درمان مشكلات جشمى بيماران را انجام

\begin{abstract}
سردبير محترم
ابوعلى حسين بن عبدالله بن سينا معروف به ابوعلى سينا يكى از بزركترين دانشمندان و متفكران ايران (Ibn Sina) و جهان اسلام است كه در ييشرفت علم يزشكى در جهان

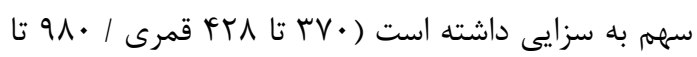
Y • • (ميلادى) [1]]. او در ايران به شيخ الرئيس و در لاتين به آوِسينا (Avicenna) معروف است. ابوعلى سينا اصلاحاتى در مباحث كالبدشناسى جالينوس انجام داد كه از ديدگاه مورخين، اين اصلاحات بر اساس تشريح، مشاهدات، تجربيات و نوآورىهاى شخصى اوست [r].
\end{abstract}

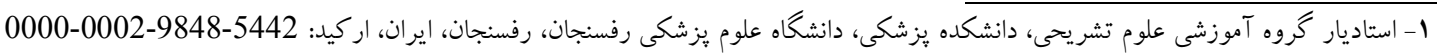

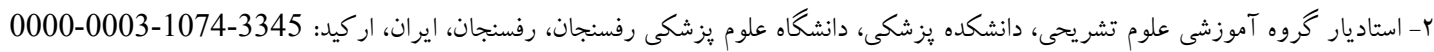

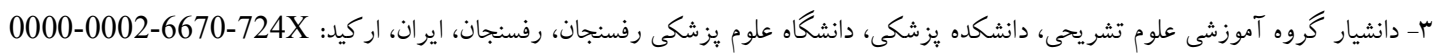

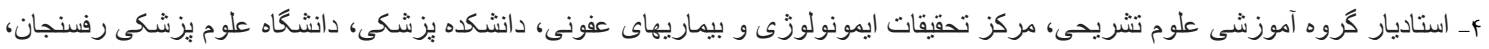

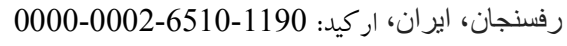

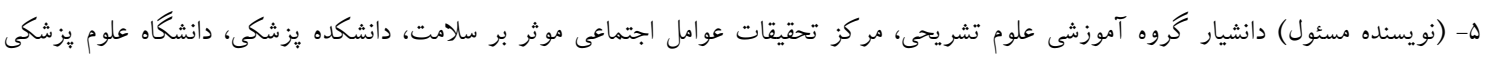

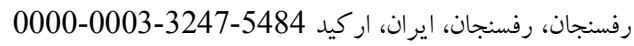

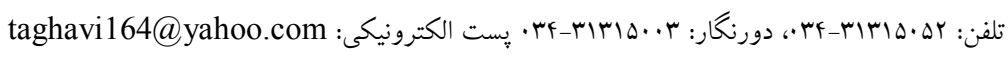




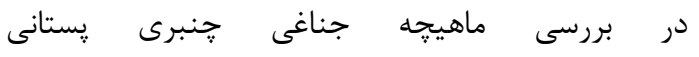
(Sternocleidomastoid Muscle) ابوعلى سينا اين عضله را شامل دو بخش جناغى و جنبرى مى دانست و نه اينكه دو ماهيجه جدا باشند و مبدأ عضله را دقيق توضيح مىدهد. تفسير او از مفهوم سر ماهيجه و بيان تفاوتهاى جزئى نشان از تشريح دقيق ماهيجهها در انسان توسط ابنسينا دارد [ه]. ابوعلى سينا در تشريح و توصيف قلب مىنويسد: اقلب را دو زائده كوش مانند است كه بر دو دهانه ورودى كه خون از آن به قلب مى آيد، قرار دارند. اين زوائد يوشيده از جربىاند و به هنگام انقباض قلبى جين مىخورند و در زمان انبساط سفت مىشوند و بخشى از آنجه را كه وارد قلب مىشود در خود محصور مى كنند. اكر ماده رطوبتى در ميان قلب و نيام آن جمع شود و ميزان آن زياد باشد، بر قلب فشار مى آورد و از گسترش باز مىمانده كه اين مطلب اشاره به يريكارديت حاد قلبى دارد. او در ارتباط با شريانهاى قلب نيز جنين توصيف مى كند كه البرخى از آنها در درازاى قلب قرار دارند، در حالى كه برخى به صورت مورب و عرضىتر طى مسير مى كنند و در قلب فرو مىروند، هم جنين بيان مىدارد ممكن است در ركهاى قلب، راه بندانهاى زيانآورى رخ دهد و كنشهاى قلب به كاستى كرايده [ع]. در ارتباط با شريانها مىنويسد: التمام شريان ها به استثناء يكى از آنها داراى دو لايه ناز كند. لايهاى كه به مثابه آستر ديواره شريان است، سختتر از لايه رويى استه [V]، و در ادامه پٍ از آن كه شاخههاى منشعب از قلب را توصيف مىكند و به شريانهاى سباتى

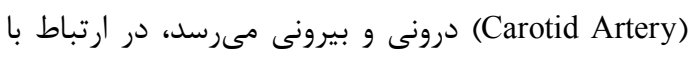

مى دهد و به راب مى گويد همه اين موارد را از يزشكى حاذق به نام ابنسينا آموخته است. راب كول كه در كودكى مادرش را به خاطر بيمارى از دست داده بود، براى دستيابى به رؤيايش و آموختن علم طب، با مشقت بسيار و با عبور از بيابانهاى صعبالعبور بالاخره خود را به ايران مىرساند و به شاكردى ابنسينا در اصفهان مىرود. علاوه بر تحريفات تاريخى فراوان اين فيلم از جمله آنكه سلجوقيان هم عصر ابنسينا معرفى شدهاند (در حالى كه آنها حدود .. أسال بعد، روى كار آمدند) و نيز اين موضوع كه ابنسينا در انتهاى فيلم با خوردن كاسه زهر خودكشى مى كند (در صورتى كه وى به كواه تاريخ از بيمارى قولنج رنج مىبرده و در اثر آن فوت كرده است)، در بخشى از آن و در طى يك عمل جراحى ابنسينا به عنوان وردست راب كول وسايل جراحى را آماده مى كند و كاركردان فيلم او را در حد دستيار يك بك كارآموز يزشكى بايين مى آورد. همرجنين در بخش ديكرى از فيلم، اين جوان اطلاعاتى از قلب و اعضاى درونى بدن را كه طى تشريح مخفيانه يك جسد و دور از نظر مأمورين حكومتى به دست آورده است به صورت شبانه و در خفا در اختيار ابن سينا قرار مىدهد. در ادامه، داستان به نحوى پيش مىرود كه گَيا ابنسينا به هيج عنوان تشريح عملى انجام نداده است و از ساختارهاى درونى بدن جز اطلاعات نظرى حيزى نمى داند [ب]. اين در حالى است كه ابن سينا عمل تشريح را در سنين جوانى انجام داده و به اعضاى بدن انسان شناخت كامل داشت، به كونهاى كه حتى بيمارىهاى يِيجيدهاى جون آب مرواريد را درمان مىكرد [4]. ابوعلىسينا در مبحث ماهيجهها نظرات جالينوس را يذيرفته است، ولى جالينوس ماهيجهها را در ميمون بررسى كرده است. به عنوان مثال 
و سبك نوشتارى و توصيفى او به نحوى است كه جز با مشاهده و تشريح اين جزئيات قابل بيان نيستند. همرجنين وريد باب را اين جنين توصيف مى كند: "وريد باب در دو انتهاى خود انشعاباتى دارد. انتهايى كه در كودى كبد فرورفته است به ينج قسمت تقسيم مىشود. انشعاباتى از آن به كنارههاى محدب كبد مىرسد و انشعابى نيز به كيسه صفرا مىرود. در طرف ديخر به هشت شاخه تقسيم مىشود كه دو انشعاب آن كوجگ و شش شاخه ديگر بزرگترند. يكى از شاخههاى كوجى به دوازدهه مىرود و از آن انشعاباتى جدا مىشود كه در لوزالمعده يراكنده مىشود "

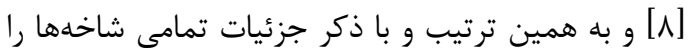
توصيف مى كند كه بىشك اين نوع توصيف دقيق همراه با ذكر تعداد و مسير شاخهها خود گواهى بر تشريح عملى و مشاهده عينى اين جزئيات توسط نويسنده كتاب مىباشد. به عنوان آخرين مثال در ارتباط با مجراى سينهاى مىنويسد: اين رگ در جانداران و به ويثه (Thoracic duct) انسان از وريد اجوف به سوى طرف جِ قلب مىرود و پس از آن به سمت مهره ينجمم سينه گرايش پيدا مى كند و بر مهره تكيه مى كند و در دندههاى هشت كانه زيرين و در ماهيجهها و ساير اعضاى پِيوسته با آنها متفرق مى گردد [a].
شريان سباتى درونى اينگونه شرح مىدهد: السيس در استخوان حجرى فرو مىرود و به شبكهاى مىرسد كه از آن تنيده شده است، به طورى كه رگهاى ريز با هم به صورت طبقه طبقه و جينهايى تار و يود آن شبكه را مىسازند. اين بخش از شريان سيس به سوى مغز بالا مىرود و جفتى از آن به وجود مى آيد كه غشاء را سوراخ مىكند و در حجم مغز متفرق مى گردد و به بطنهاى مغز و يوست نازى بطنهاى مغز وارد مىشود و در آنجا دهانه انشعاباتش به دهانه انشعابات رگهاى يايينرو وريدى مىرسد. از آنجا كه روح موجود در شريان لطافت و جنبشى دارد كه مىتواند مغز را گرمى بخشد و نيازمندى آن را برآورده كند، براى يذيرش آن، شبكهاى در زير مغز گسترده شده كه خون شريانى و روان كه در شريان است در شبكه توزيع گردد و بعد از يخته شدن با مغز هم مزاج شود و آنغاه از راه شبكه كه در بين استخوان و غشاء سفت قرار دارد، به طور تدريجى به مغز انتقال يابده [V]. كه در اين مطلب اشاراتى به عبور شريان سباتى درونى از درون سينوس غارى، و همرجنين اشاراتى به لايه نرم شامه درون بطن و تشكيل حلقه شريانى مغز يا حلقه ويليس دارد

\section{References}

[1] Shoja MM, RS. Tubbs, The disorder of love in the Canon of Avicenna (AD 980-1037). American Journal of Psychiatry 2007; 164(2): p. 228-29.
[2] Zargaran A, et al. Avicenna (980-1037 AD). Journal of Neurology 2012; 259(2): p. 389-90. 
[3] https//:en.wikipedia.org/w/index.php? title = The_Physician_(2013_film)\&oldid=102312896 3.

[4] Nejabat M, et al. Avicenna and cataracts: a new Analysis of Contributions to Diagnosis and Treatment from the Canon. Iranian Red Crescent Medical Journal 2012; 14(5): p: 265.

[5] Alghamdi MA, JM. Ziermann, R. Diogo, An Untold Story: The important contributions of Muslim Scholars for the Understanding of Human Anatomy. The Anatomical Record 2017; 300(6): p. 986-1008.
[6] Avicenna. Canon of medicine, translated into persian by Sharafkandy A. Vol. III (S1). Tehran: Soroosh Press; 1988; 513-4.

[7] Avicenna, Canon of medicine, translated into Persian by Sharafkandy A. Vol. I (S1). Tehran: Soroosh Press; 1988; 135-6.

[8] Avicenna, Canon of medicine, translated into Persian by Sharafkandy A. Vol. I (S2). Tehran: Soroosh Press; 1988; 141-2.

[9] Avicenna, Canon of medicine, translated into Persian by Sharafkandy A. Vol. I (S3). Tehran: Soroosh Press; 1988; 144-5. 